\title{
INFORMAL \& FORMAL DEVELOPMENTS ON THE PREMISES OF SUFI SHRINES IN PUNJAB
}

\author{
Ghafer Shahzad*
}

\section{ABSTRACT}

Built environment of Muslim shrines in the province of Punjab, Pakistan is incessantly changing. This phenomenon is gone faster from the year 1980 onward with the reconstruction of Data Darbar Complex ${ }^{1}$ in Lahore. It has set new trends for extension of Sufi shrines and their attached buildings, under administrative control of the Auqaf \& Religious Affairs Department, Government of Punjab ${ }^{2}$. This paper focuses the process of development works taken up on the premises of Muslim shrines in Punjab. For convenience, the developments in the built environment of Sufi shrines have been categorized into two main heads i.e. Informal \& Formal. Informal developments are contributions of the both; devotees and the gaddi nashins, whereas Formal developments are carried out by the administrative department i.e. Auqaf, after going through the process of proper designing and construction. The impetus and motives behind such interventions and additions vary in nature depending upon the Sufi, location and scale of shrine, number of visitation, income received, political standing etc. Studying these Informal and Formal developments, a modus operandi was devised based on the data available with the Punjab Auqaf Department and the mutawallies. After identifying such shrines in Punjab, studies were carried out to reach the conclusions. Transformation of such sacred spaces was sensitively evaluated to trace out the changed ambience of newly constructed shrines. Finally, the impact of these informal and formal developments on the socio-religious and built environment of shrines has been delved.
\end{abstract}

Keywords: Shrine, environment, interventions, heritage, restoration, sacred space, mosque, waqf properties.

\section{INTRODUCTION}

Archival records, site visits and situation analysis of the burial places of Sufis belonging to various Sufi orders in Punjab reveal that the built environment of shrines is continuously transforming into a new version since past few decades. This transformation is occurring in both ways, Informal and Formal. Informal Developments ${ }^{3}$ are initiated or carried out on the premises of shrine complex as and when required or demanded by the visitors, devotees, religious organizations ${ }^{4}$, government authorities, and politically influential persons. Annual Development Programme (ADP) of the waqf administration encompasses Informal Developments ${ }^{5}$ which are planned on annual basis. Such development schemes are conceived and planned by the Engineering Directorate ${ }^{6}$ of waqf department. These development schemes are administratively approved and technically sanctioned by the competent authorities ${ }^{7}$ before floating the tenders in print media for open tenders. Such schemes are executed, following the prescribed government procedure as laid down by the Communication and Works Department (C \& W), Government of Punjab, through their enlisted contractors.

* Dr. Ghafer Shahzad, Director Infrastructure (SDWCLP), Sustainable Development of Walled City Lahore Project, Lahore.

1 Hazrat Ali Hujwairi commonly known as Hazrat Data Gunj Bukhsh migrated from Ghazni, Afghanistan and settled in Lahore in the early decades of $11^{\text {th }}$ century CE.

2 Auqaf Department was established in 1960 under Waqf Properties Ordinance 1959 (revised in 1979) to look after and administer the waqf properties. It is headed by Secretary/Chief Administrator with six directorates (Finance, Estate, Administration, Health, Religious Affairs and Projects) at head office and 13 number Zonal Offices in Punjab.

3 Informal developments include additions, alterations, repairs, reconstructions and restorations in the built environment of Sufi shrines.

4 Anjuman-e Khuddam-e Awliya, Tanzeem Tahafuz-e Mazarat, Religious Purpose's Committees etc.

5 Informal Developments include construction of lavatory \& ablution blocks, rooms and verandas, shoe-keeping areas, guest rooms, dispensaries, shops, madrassahs, etc.

6 Engineering Directorate comprises Director Projects (BPS 19), three Executive Engineers (BPS 18), eight Sub Divisional Officers (BPS 17), twelve Sub Engineers and one post of Deputy Director Architecture (BPS 18).

7 Administrative Approval is accorded by the Secretary/Chief Administrator Auqaf and Technical Sanction is given by the Chief Engineer/Director Projects Auqaf. 
There are some cases when designing of shrine complexes are conceived holistically and master plans are prepared and implemented ${ }^{8}$. Such cases have been classified here as formal developments. For large scale development projects, Federal or Provincial governments are involved who direct the waqf administration while providing the funds for execution of shrines. Such schemes, for their architectural designing are announced in the print media for open competitions among the architects. Design Selection Committees constituted for the purpose finally select the best architectural design proposals, keeping in view certain pre-defined criteria and parameters.

\section{MODUS OPERANDI}

To gauge the nature of physical changes and interventions made in the built environment of shrines, Annual Development Programmes (ADP) of waqf administration for the last four years ${ }^{9}$ was taken and a development scheme [Refer Table-1] was derived for study and analysis. There are two types of shrines found in Punjab i.e. flat-roofed and domed (Mumtaz, 1985a). The buildings on the premises of shrine performing various functions were categorized into various typologies for mutual comparison, based on yearwise development. The development budget for these four years was also compared. The development scheme gives real trends regarding the nature and pace of transformation of the built environment of shrines during last few decades.

Development scheme is further based on the following assumptions;

1. For informal developments, waqf administration prepares plans every year to re-construct, repair, and restore the dilapidated individual buildings of shrines, attached mosques, public amenities, water supply arrangements, commercial buildings, verandas and rooms, courtyard flooring, boundary walls etc.

2. The number of re-constructed mosques in the precincts of the shrines is increasing as compared to the number of re-constructed shrines. This indicates the deviation of the focus of waqf administration from its core objective of taking care of the shrines under their administrative control and providing the basic facilities to 'zaireen' (visitors).

\begin{tabular}{|c|c|c|c|c|c|c|c|c|c|}
\hline $\begin{array}{c}\text { Type of } \\
\text { Interventions }\end{array}$ & Nature & \multicolumn{2}{|c|}{$\begin{array}{c}\text { Year } \\
2006-7\end{array}$} & \multicolumn{2}{|c|}{$\begin{array}{c}\text { Year } \\
2007-08\end{array}$} & \multicolumn{2}{|c|}{$\begin{array}{c}\text { Year } \\
\text { 2008-09 }\end{array}$} & \multicolumn{2}{|c|}{$\begin{array}{c}\text { Year } \\
2009-10\end{array}$} \\
\hline Building Type & Renovation & \multicolumn{8}{|c|}{ Number of Development Schemes } \\
\hline \multirow[t]{2}{*}{ Shrine } & & 3 & \multirow[t]{2}{*}{12} & 5 & \multirow{2}{*}{13} & 3 & \multirow{2}{*}{15} & 4 & \multirow[b]{2}{*}{9} \\
\hline & Reconstruction & 9 & & 8 & & 12 & & 5 & \\
\hline \multirow[t]{2}{*}{ Mosque } & Renovation & 8 & \multirow[t]{2}{*}{26} & 9 & \multirow[t]{2}{*}{28} & 10 & \multirow[t]{2}{*}{34} & 9 & \multirow[b]{2}{*}{22} \\
\hline & Reconstruction & 18 & & 19 & & 14 & & 13 & \\
\hline \multirow[t]{2}{*}{$\begin{array}{l}\text { Verandal } \\
\text { Room }\end{array}$} & Renovation & 4 & \multirow[t]{2}{*}{16} & 3 & \multirow[t]{2}{*}{12} & 0 & \multirow[t]{2}{*}{7} & 0 & \multirow[b]{2}{*}{9} \\
\hline & Reconstruction & 12 & & 9 & & 7 & & 9 & \\
\hline \multirow[t]{2}{*}{$\begin{array}{c}\text { Public } \\
\text { Amenities }\end{array}$} & Renovation & 10 & \multirow[t]{2}{*}{28} & 18 & \multirow[t]{2}{*}{45} & 11 & \multirow[t]{2}{*}{38} & 13 & \multirow[b]{2}{*}{29} \\
\hline & Reconstruction & 18 & & 27 & & 27 & & 16 & \\
\hline $\begin{array}{c}\text { Commercial } \\
\text { Buildings }\end{array}$ & Construction & $\cdot$ & 22 & $\cdot$ & 16 & - & 18 & - & 10 \\
\hline $\begin{array}{c}\text { Courtyard } \\
\text { Flooring / } \\
\text { Boundary } \\
\text { Wall }\end{array}$ & Construction & - & 14 & - & 17 & & 13 & - & 8 \\
\hline \multirow[t]{2}{*}{$\begin{array}{l}\text { Water Supply } \\
\text { Arrangement }\end{array}$} & Water Pumps & 12 & \multirow[t]{2}{*}{13} & 8 & \multirow[t]{2}{*}{9} & 10 & \multirow[t]{2}{*}{12} & 6 & \multirow[b]{2}{*}{7} \\
\hline & Tube Wells & 1 & & 1 & & 2 & & 1 & \\
\hline \multicolumn{2}{|c|}{ Total Number of Schemes } & \multicolumn{2}{|c|}{131} & \multicolumn{2}{|c|}{140} & \multicolumn{2}{|c|}{137} & \multicolumn{2}{|c|}{94} \\
\hline \multicolumn{2}{|c|}{ Budget Allocation } & & & & & & & & \\
\hline
\end{tabular}

Table-1: Development Scheme Based on Annual Development Plans of Auqaf Department (fiscal years 2006-07, 2007-08, 2008-09, 2009-10).

8 Shrine complexes of Hazrat Ali Hujwiri, Baba Bulleh Shah, Imam Bari Sarkar etc are few examples of Formal Developments as were conceived and designed holistically by the architectural consultants and funded by the Federal and Provincial governments. 9 Annual Development Budgets for the years 2006-07, 2007-08, 2008-09 \& 2009-10 were taken for framing of Development Matrix (Table 01). Period 4 years was taken as any large scale development scheme is spread at the maximum over four years in financial provision. 
3. Construction of commercial buildings i.e. shops, offices etc at the open waqf land in urban areas has become top priority of the waqf administration. The objective is to generate money from such urban rental properties.

After identifying the shrines and mosques under administrative control of the waqf administration ${ }^{10}$, either newly constructed or renovated, visits were made to analyze the situation. Meetings were held with the 'gaddi nashins', administrators and 'mutawallies' to trace out the construction activities performed during last twenty years. The changing trends of the built environment were studied by making photographic or graphic documentation [Refer Figure-1, 2, 3 and 4].

\section{INFORMAL DEVELOPMENTS}

According to the development scheme based on the annual budget for the last four years, along with the site visits and physical verifications, informal developments on the premises of shrine comprise following building types;

\subsection{Re-construction of Shrines}

Shrine is a key building structure on the premises of waqf property around which charisma of life (based on the rituals and ceremonies) happens. In pursuance to the Waqf Properties Ordinence 1960 and Special Premises Preservation Act 1985, shrines being historical and cultural buildings have been placed under two heads;

1. Shrines where waqf organization has full administrative control and responsibility for the maintenance and reconstruction of old buildings.

2. Shrines included in the list of protected monuments where only Archaeology Department has the mandate for restoration.

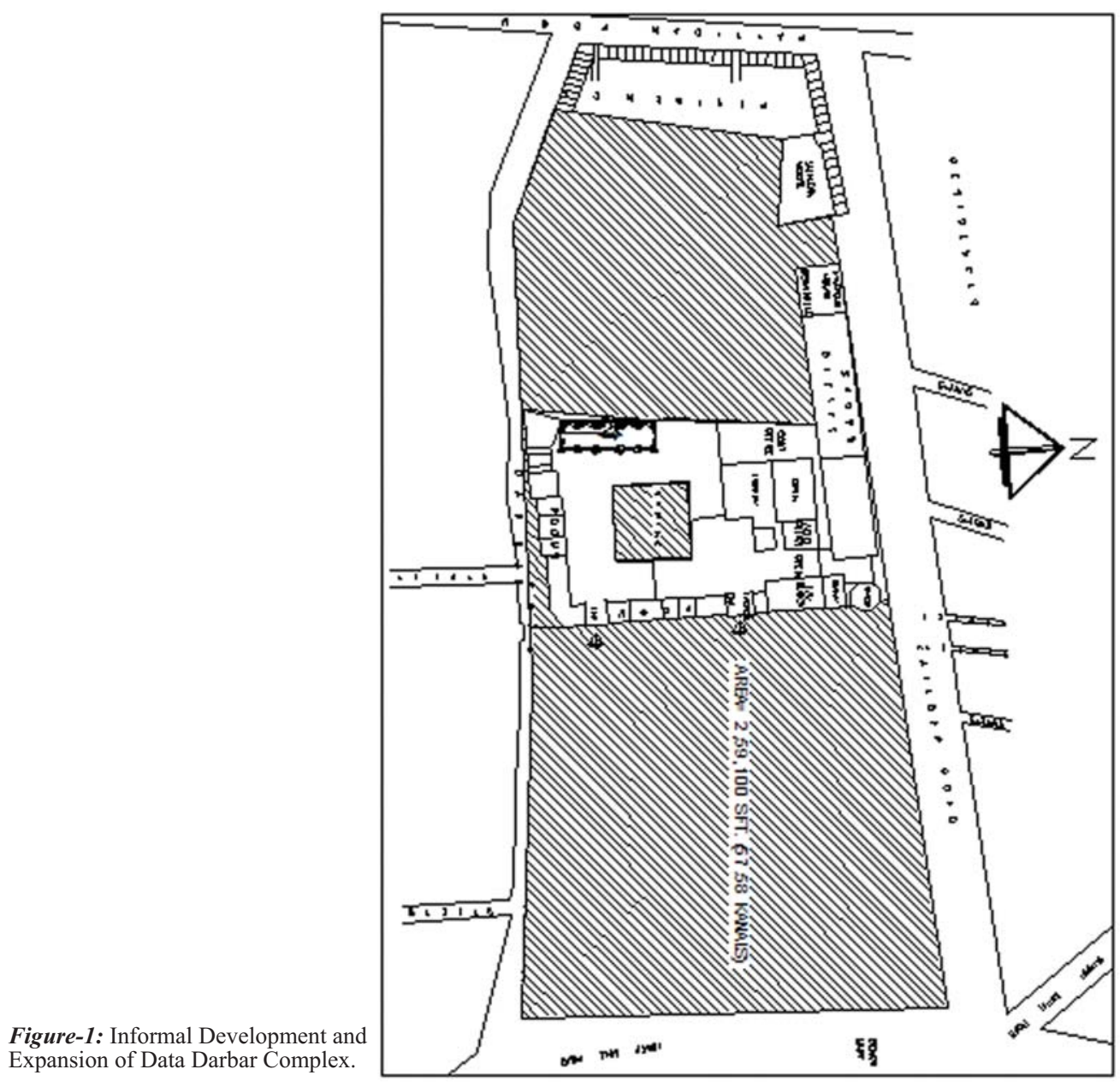

10 Auqaf department maintains and administers 530 shrines in Punjab. 
Shrine buildings are re-constructed, repaired, restored, added, altered and extended on regular basis to fulfill the requirements and demand of visitors ${ }^{11}$. For less popular, less visited shrines, re-construction is carried out on the same footing of the previous building. In case, if land is available, larger size shrines along with ancillary buildings are constructed to provide more space to the visitors. The shrine complex of Hazrat Ali Hujwiri [Figure-1] was initially spread over 3125 sq. yard ${ }^{12}$ but during the period of General Muhammad Zia al Haq, President of Pakistan, its area was extended to 29000 sq. yard ${ }^{13}$ and more than 33333.33 sq. yard built-area has been added in the complex ${ }^{14}$. This tremendous change in the built environment has discontinued the old incremental development practice and created a new trend in the tradition of khanqah construction in the Indian Subcontinent.

Baba Farid was buried in his hujra where he took his last breath. His house was turned into khanqah. Later on a small mosque, rooms, verandas, were added and a small burial place transformed into a khanqah [Figure-2]. The area of shrine premises of Baba Farid Pakpattan was 11600 sq. yard along with 12 commercial units and 5412 acre waqf agricultural land when it was taken over by the Auqaf Organization in 1960. The land towards the western and southern sides of the shrine of Baba Farid was acquired ${ }^{15}$ by the waqf organization to expand the boundaries of the shrine Baba Farid and create a new entrance from the Sahiwal Road to facilitate the devotees [Figure-3]. During construction and expansion, various old structures like Burj Nizamai, Burj Sabiri and Burj Jamali ${ }^{16}$ were demolished although having heritage and historical value. There was an old mosque of Tughlaq period on the premises of shrine Baba Farid which was demolished in 1999 C.E. when construction of new mosque started in compliance to the directions of the then Prime Minister.
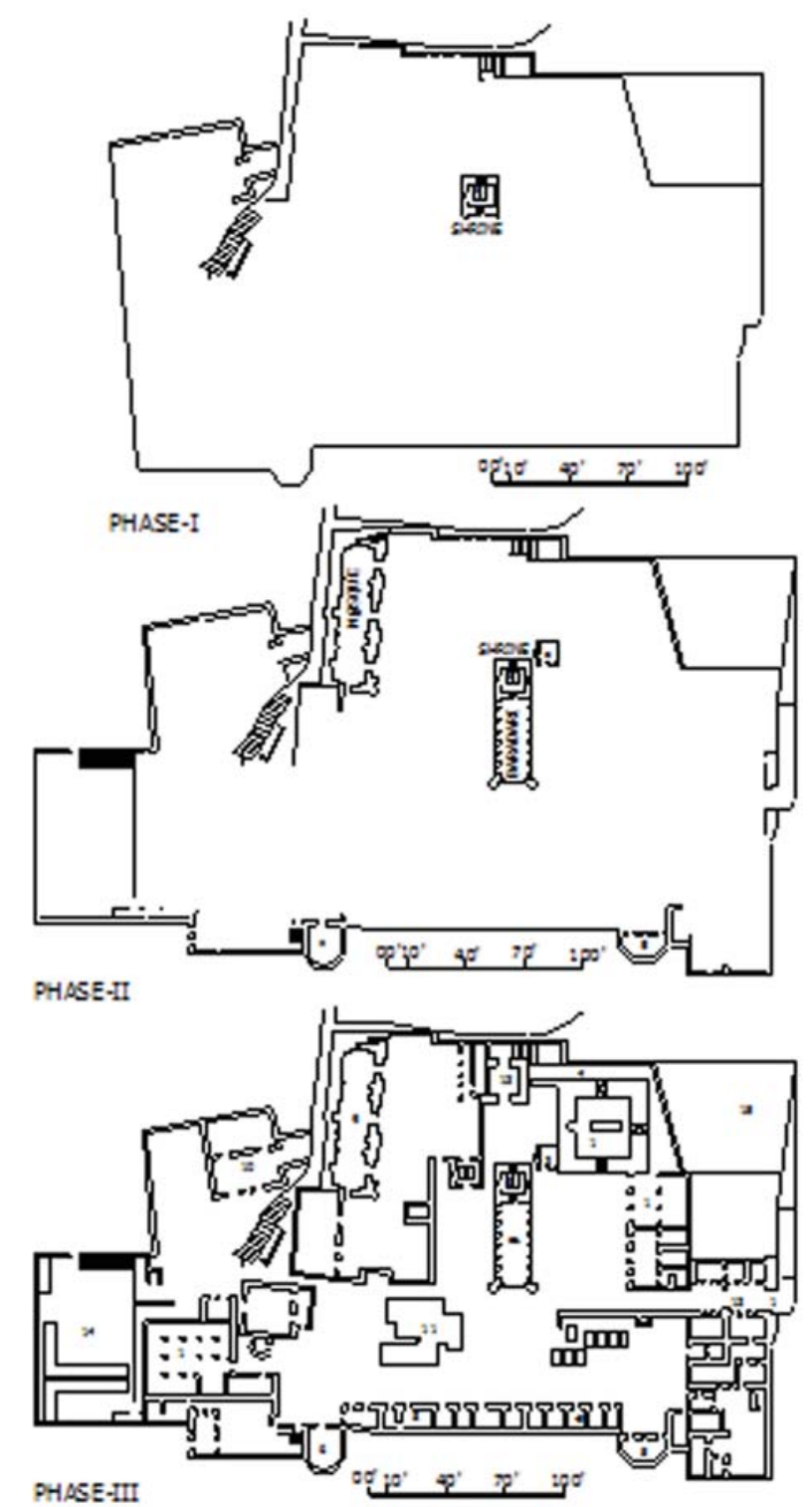

Figure-2: Three phases of Informal developments at the old shrine of Bâbâ Farîd

11 In the past years (from 1993 to 2012), shrines of Hazrat Badshahn Khoshab, Sakhi Saiden Sherazi, Baba Bulleh Shah, Abdul us Salam Chishti Bara Bhai Masroor, Sialkot, Hazrat Qutab Shah Wali Narowal, Hazrat Suleman Paras Jhelum, Hazrat Pir Maqbool Muftian Dina, Jhelum, Hazrat Shah de Taaliyan Rawalpindi, Hazrat Pir Ghaib Shah Rawaat, Baba Shah Jamal Shaikhupura, Ghoray Shah Lahore, Baba Kamal Chishti Kasur, Hazrat Bibi Pak Damanan Lahore, Hazrat Syed Turat Murad Lahore, and many others have been reconstructed during last twenty years.

12 Shahzad, Ghafer (2012) Muslim Shrines in Urban Settlements Sang-e Meel Publications Lahore p.143

13 Shahzad, Ghafer (2007) Data Darbar Complex-Taamer say Takmeel Tak, Sang-e Meel Publications Lahore

14 Data Darbar Complex was conceived and designed in 1980-81 and completed in 1999. It took almost 20 years to complete the project because of non-availability of funds from the provincial and federal governments.

15 A patch of land measuring 1 kanal 16 marlas at the rear of the old mosque was purchased by spending an amount of Rs 3.0 million in the year 1997. More land was acquired towards southern side to give direct approach to the shrine from Sahiwal Road.

16 Burj Jamali was dedicated to Hazrat Jamal al-Din Hanswi, Burj Nizamai dedicated to Hazrat Nizam al-Din Awliya' and Burj Sabiri to the Shaykh 'Ala' al-Din 'Ali Ahmed Sabir of Kalyer Sharif. These three Sufis were khulafa of Baba Farid. 
Senior experts, who were members of a committee constituted by the Governmnet of Punjab, criticized this action in a strong manner.

Similarly, the old shrines included in the list of protected monuments were demolished and re-constructed without taking permission from the committee. Every year, waqf administration plans to re-construct the old dilapidated buildings (which are not included in the protected enlisted monuments) of ten to twenty shrines in number, keeping in view the annual budget constraints and the demand of public and public representatives. The old dilapidated shrines are re-constructed on top priority basis. The usage of modern building materials and construction techniques has transformed the shrine into modern form and aesthetics [Figure-4]. This has started changing the visual and aesthetical value of the built environment of shrines. Being associated with the old building form, devotees resist such demolition and re-construction.

\subsection{Re-construction of Attached Mosques}

Historical studies inform that mosque has never been an essential component of a shrine complex or khanaqah ${ }^{17}$. In the earliest shrine of Khaliq Walid, a musalla Mehrab has been found in the western wall (Khan, 2003a, Hasan, 2001a). It is created as an elaborate arched recess in the centre of outer wall (Khan, 1991a). From the outset, a small defined space in the western wall of the Chishty shrines was earmarked for performance of prayer (Khan, 1990a). At the shrine of Baba Farid, a small prayer space i.e. Masjid Nizam al-Din Auwliya (Khan, 1990b) was present that still exists. During the Tughlaq period, a large mosque was constructed towards western side of the shrine Baba Farid (Khan, 1990c) which has been now replaced by a big Jamia Mosque (19992005). After death of the Sûfî when visitation increased in number, need of a large size prayer hall was realized, but its scale remained smaller and shrine kept on holding its key position on the premises.

From year 1990 CE onward, a trend for construction of a big jami'a mosque was introduced when a large mosque was constructed on the premises of shrine of Hazrat 'Alî Hujwiri [Figure-5]. It completely changed the socio-religious and built environment of the shrine complex. Continuing the trend, new mosques were constructed at the shrines of

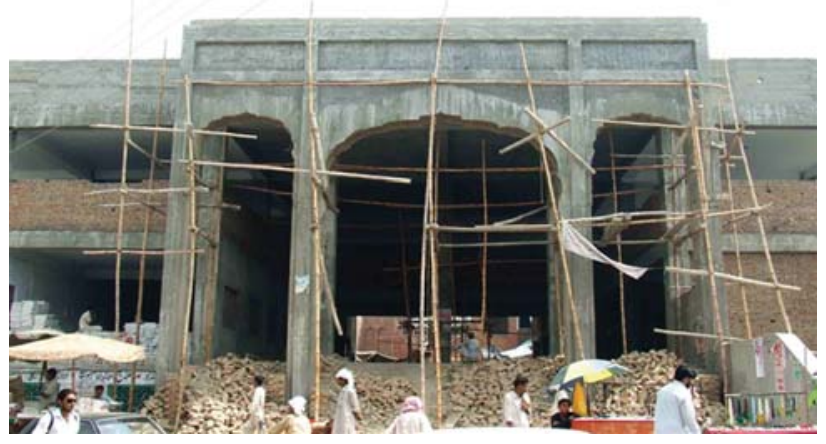

Figure-3: Newly constructed Entrance from Sahiwal Road to the shrine of Bâbâ Farîd.

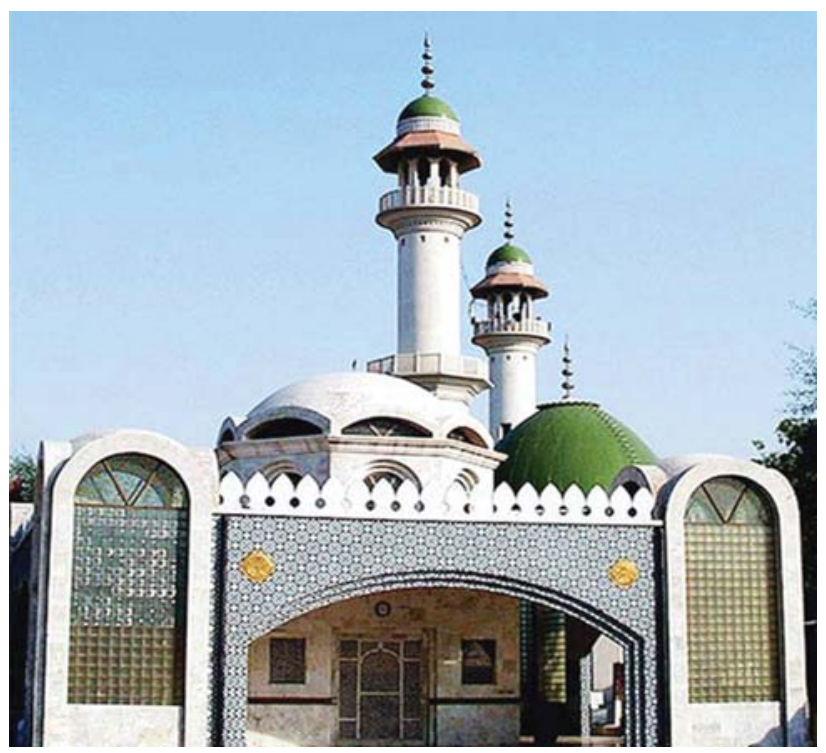

Figure-4: Newly constructed shrine of Baba Bulleh Shah (2005-07) at Kasur.

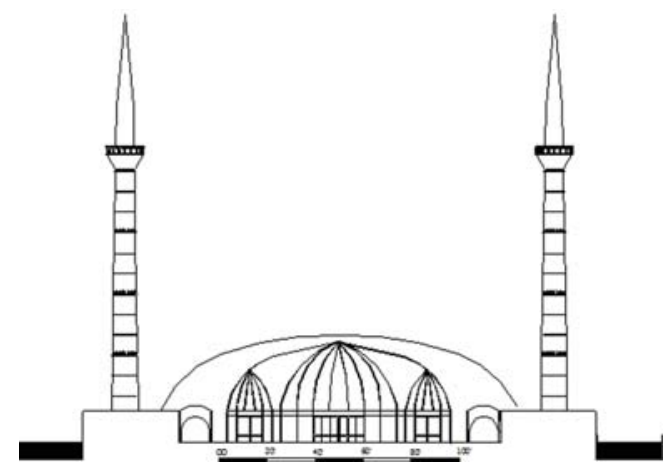

Figure-5: New Mosque Data Gunj Bukhsh. 
Baba Farid [Figure-6] Baba Bulleh Shah, Shah Hussain, Hazrat Sakhi Saiden Sherazi etc. These modern Jami'a Mosques have introduced other functional components like lavatory, ablution, air conditioning system, parking etc. Today, it has become difficult to segregate the boundaries of mosque and shrine in a complex.

It was not problematic when mosque was constructed for the need of za'ireen. The trend of construction of a large size mosque with tall minarets on the premises of shrine created a strong impact on the physical and religious environment of the shrine complex. Table 02 gives a comparative study of the newly constructed and old demolished mosques, attached to the shrines in the province of Punjab during last three decades. Today, the spiritual ambiance ${ }^{18}$ of shrines is at stake after dominancy of the mosque attached to a shrine complex.

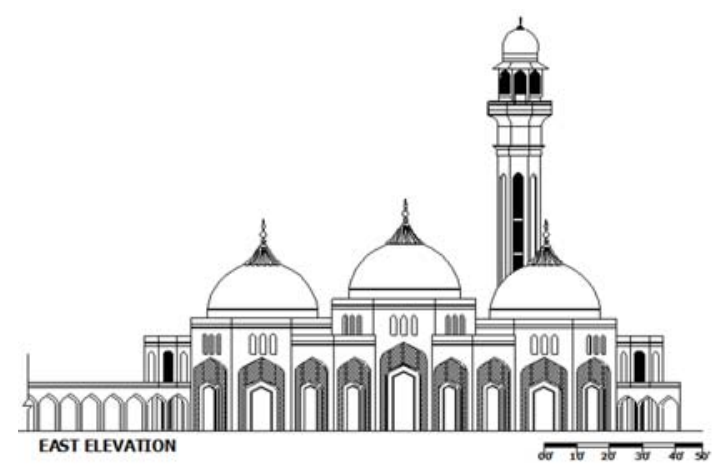

Figure-6: New Mosque Baba Farid.

Every year, waqf administration plans to re-construct 20 to 30 mosques attached to the shrines (Refer Table 02).

\begin{tabular}{|c|c|c|c|c|c|}
\hline Name of Mosque & $\begin{array}{c}\text { Size of } \\
\text { Prayer Hall }\end{array}$ & Location & $\begin{array}{l}\text { Minaret } \\
\text { Height }\end{array}$ & $\begin{array}{l}\text { Enlisted } / \\
\text { Protected }\end{array}$ & $\begin{array}{c}\text { Year of } \\
\text { Construction }\end{array}$ \\
\hline \multicolumn{6}{|c|}{ 1. Mosque Hadrat Ali Hujwiri: Lahore } \\
\hline Old Mosque & $85 \times 18^{\prime}$ & West of shrine & $38^{\prime}$ & Protected & $19^{n}$ Century \\
\hline New Mosque & $120^{\circ} \times 80^{\circ}$ & West of shrine & $190^{\circ}$ & - & 1989 \\
\hline \multicolumn{6}{|c|}{ 2. Mosque Baba Bulleh Shah: Kasur } \\
\hline Old Mosque & $38^{\prime} \times 14^{\prime}$ & S.W. of shrine & - & Protected & $19^{n}$ century \\
\hline New Mosque & $80 \times 40^{\circ}$ & S.W. of shrine & $88^{\prime}$ & - & 2004 \\
\hline \multicolumn{6}{|c|}{ 3. Mosque Baba Farid: Pakpattan } \\
\hline Old Mosque & $76 \times 21^{\circ}$ & West of shrine & - & Protected & $14^{\text {"n century }}$ \\
\hline New Mosque & $130 \times 54^{\prime}$ & West of shrine & $98^{\circ}$ & - & 2005 \\
\hline \multicolumn{6}{|c|}{ 4. Mosque Sakhi Saiden Sherazi: Choa Saiden Shah } \\
\hline Old Mosque & $34 \times 18^{\prime}$ & Esst of shrine & $\begin{array}{ll}- \\
-\end{array}$ & - & $20^{\prime \prime}$ century \\
\hline New Mosque & $76 \times 38^{\circ}$ & N.W. of shrine & $78^{\prime}$ & - & 2007 \\
\hline \multicolumn{6}{|c|}{ 5. Mosque Hadrat Abu al-Khair Nau Lakh Hazari: Shahkot } \\
\hline Old Mosque & $24 \times 12$ & S.E. of shrine & - & Protected & $20^{m}$ century \\
\hline New Mosque & $34 \times 18^{\prime}$ & S.E. of shrine & 42 & - & 2010 \\
\hline \multicolumn{6}{|c|}{ 6. Mosque Shah Hussain: Lahore } \\
\hline | Old Mosque & $38 \times 16^{2}$ & West of shrine & $38^{\prime}$ & Protected & $16^{\text {"century }}$ \\
\hline New Mosque & $63^{\circ} \times 40^{\circ}$ & West of shrine & $88^{\prime}$ & - & 2010 \\
\hline \multicolumn{6}{|c|}{ 7. Mosque Hadrat Noshah Ganj Pak: Runmal Sharif } \\
\hline Old Mosque & $26 \times 16^{\prime}$ & S.W. of shrine & - & - & $20^{2 n}$ century \\
\hline New Mosque & $42 \times 22^{\circ}$ & S.W. of shrine & 42 & - & 2010 \\
\hline \multicolumn{6}{|c|}{ 8. Mosque Pir Ahmad Qatal: Jalalpur Pirwala } \\
\hline Old Mosque & $48 \times 22$ & S.W. of shrine & - & Protected & $18^{m n}$ century \\
\hline New Mosque & $48 \times 22$ & S.W. of shrine & - & - & 2003 \\
\hline \multicolumn{6}{|c|}{ 9. Mosque Miyan Muhammad Bukhsh: Mirpur } \\
\hline Old Mosque & $26 \times 14$ & N.W. of shrine & - & - & $20^{\prime \prime}$ century \\
\hline New Mosque & $60 \times 60^{\circ}$ & N.W. of shrine & $73^{\circ}$ & - & 2006 \\
\hline
\end{tabular}

Table-2: Comparative study of newly constructed and old demolished mosques attached to the shrines. (Source: Punjab Auqaf Department)

18 The Spiritual ambience of a shrine is mainly based on performance of rituals, ceremonies, beliefs, 'urs celebrations etc related to the Sufi and his order. 
The trend of re-construction of a large size jami'a mosque is alarming and is changing the socio-religious and built environment of shrine altogether. Socio-religious environment of shrine complex is becoming more Islamized rather than Islamicate. This trend has also encouraged the demolition of the old mosques [Figure-7, 8 and 9] which were enlistedprotected in terms of Punjab Special Premises (preservation) Ordinance 1985. According to the information given in the Table 02, six enlisted-protected mosques in the Punjab have been demolished and reconstructed. ${ }^{19}$

\subsection{Public Amenities \& Commercial Buildings}

Public amenities include construction of lavatory and ablution blocks and water supply arrangements on the premises of shrine complex. Every year, thirty five to forty development schemes are approved under head of public amenities in the Annual Development Programme of waqf administration. Every body entering the shrine essentially needs to purify with water for taharat and wadu. These facilities are essentially required to be located at the entrance of a shrine complex. Their presence has changed the physical environment in areas near entrance [Figure-10]. Provision for shoe-keeping area is also getting importance.

These buildings are constructed only to fulfill the functional need and their aesthetical value is ignored. These structural additions are very important because of their prime location

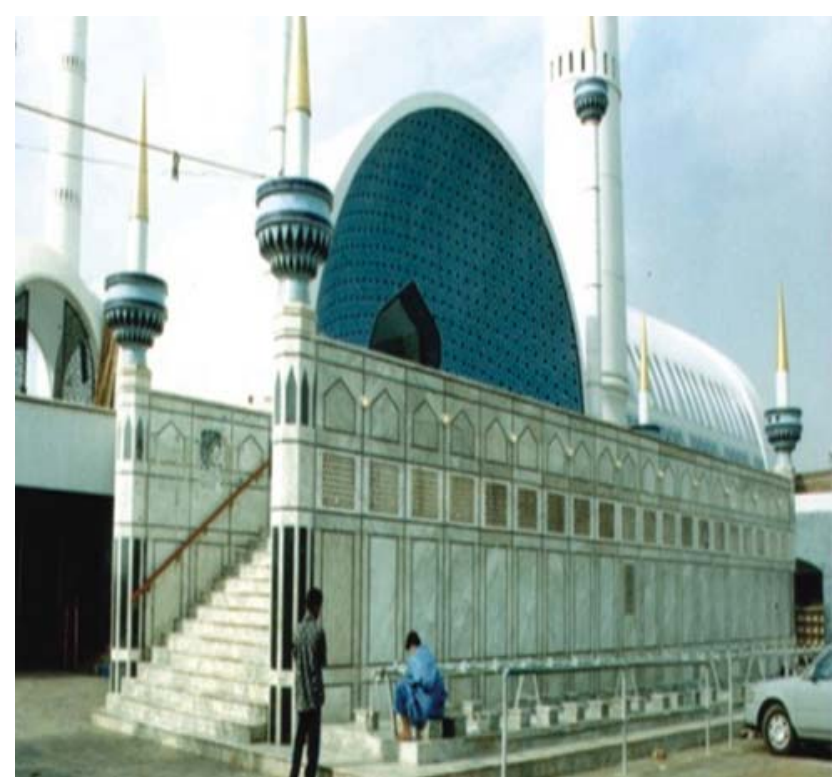

Figure-10: Entrance/Wazu Place at shrine Hazrat Data Gunj Bukhsh

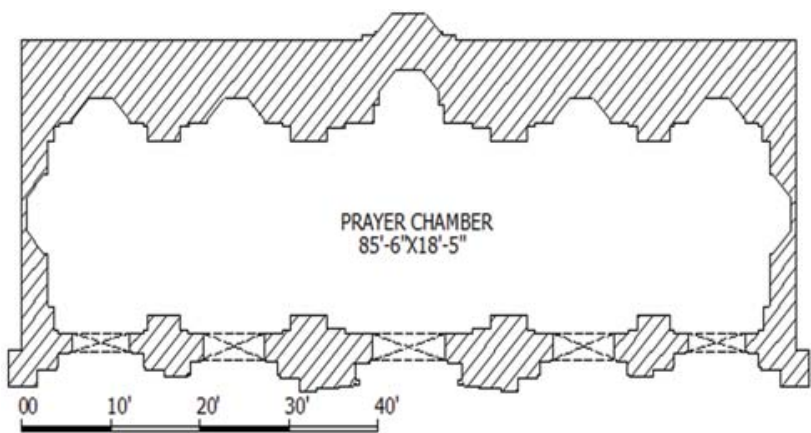

Figure-7: The plan of old mosque Hazrat Ali Hujwiri demolished in 1986.

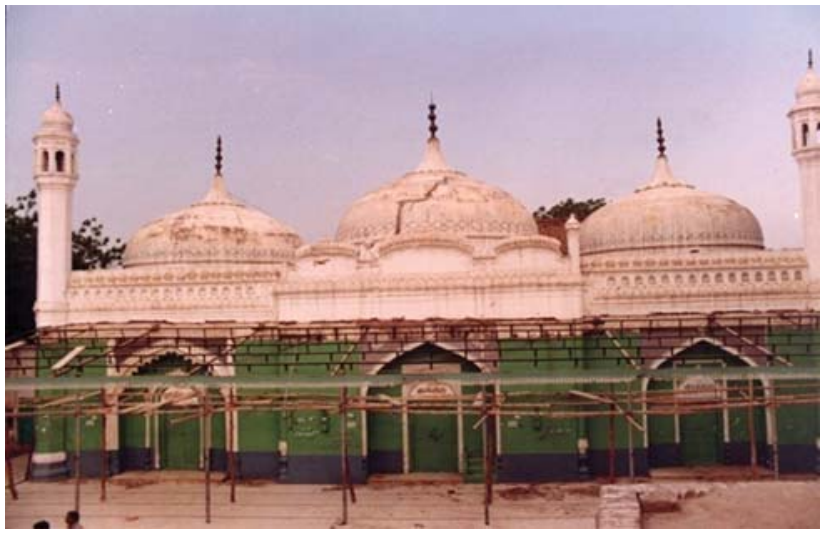

Figure-8: Tughlaq Period Mosque Baba Farid demolished in 1999

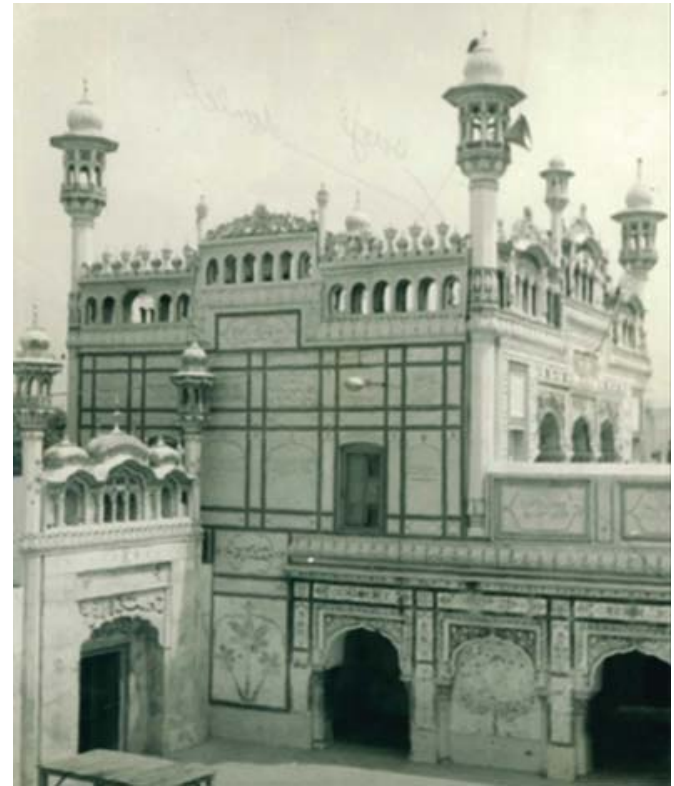

Figure-9: Mosque Abu al-Khair Nau Lakh Hazari Shahkot demolished in 2008

19 According to the Punjab Special Premises (preservation) Ordinance 1985, no one can reconstruct, add or demolish any structure within circle of 200 feet all around the enlisted protected monuments. Such action is punishable. 
as visitors interact with these spaces first while entering the shrine premises ${ }^{20}$. Similarly, for water supply arrangements, a room for tube-well and structure for overhead water reservoir ${ }^{21}$ demand attention for their proper location and design of building form.

Waqf administration is always interested in exploiting the commercial potential of the open waqf land in the urban areas. Their point of view, for its best utilization is to construct shops or office buildings for rental purposes. At the outer periphery of waqf land, such shops are constructed. ${ }^{22}$ Shrines have been confined in the narrow rows of shops and sometimes, even their main entrances are not visible from the outside. ${ }^{23}$

Another trend is to rent out the space temporarily for Sunday's and Friday's shops. ${ }^{24}$ Waqf Organization collects a handsome amount from the rents of these temporary shops or commercial units every month. ${ }^{25}$ These commercial activities, either permanent or temporary, influence the physical and spiritual ambiance of the shrine complex.

Adding of small building components like verandas, rooms, courtyard flooring, etc on the premises of shrine complex is a regular feature of the Annual Development Programme (ADP) of waqf organizations. Visitors often demand such facilities and they also give donations for such construction. Every year, waqf administration approves twenty to thirty such development schemes in their development budget [Refer Table-1]. As little importance is being given to these requirements, such additions have no visual relation with the existing building forms. These additions appear out of place and uncongenial on the premises of the shrine complex.

\section{FORMAL DEVELOPMENTS}

The holistic approach for re-construction of a shrine complex ${ }^{26}$ is the recent phenomenon. It started with the design competition of Data Darbar Complex in the year 1981. Previously only informal developments were carried out either by the waqf department or the mutawallis. Data Darbar Complex conceived by the architectural consultant ${ }^{27}$ introduced new concept for master planning of the shrine complex in Pakistan [Figure-11] based on institutional building designing approach. First time, a big jami' a mosque was added in a shrine complex under direction of the then President of Pakistan in 1981. The architectural features were kept modern and new building materials were used for its building form ${ }^{28}$. It was a first deviation from the traditional construction and decoration techniques far case of shrine buildings.

In Data Darbar Complex, for the first time new components in shrine complex were introduced i.e. car parking in basement, air-conditioning plant, sama'a hall in semi basement, seminar hall, library, police post, lost \& found center, office for jahez (dowry) committee etc. Architectural design approach of Data Darbar Complex influenced other shrine complexes like Barî Imâm Sarkâr Complex, Miyân Muhammad Bukhsh Shrine Complex, Baba Bulleh Shah Shrine Complex etc. This new concept has totally changed the socio-religious and built environment of the shrine. Construction of a big mosque has encouraged the daily, weekly, monthly and annual ceremonies in the prayer hall parallel to the shrine.

On great public demand and keen interest of the Federal and Provincial governments for expansion of frequently

20 Wadu place, Taharat Khanas and Shoe-Keeping areas were not taken into consideration while designing the Data Darbar Complex, Baba Farid Complex, Baba Bulleh Shah Complex etc. Their later addition has created many visual and functional problems.

21 The over head water reservoir of 20,000 gallons is placed in the entrance area of the shrine of Baba Farid Pakpattan.

22 On the periphery of newly constructed zaireen complex and mosque at shrine of Madhu Lal Hussain Lahore, the shops are constructed for rental purpose. Similarly, when zaireen complexes at shrines of Sakhi Sarwar Dera Ghazi Khan and Baba Farid Pakpattan were constructed, shops were also built.

23 The passage to the shrines of Hazrat Bibi Pakdamana Lahore and Pir Abdul Razzaque Makki Sharif Lahore are flanked with shops in a way as no one can see the entrances to these passages giving access to the shrines.

24 At the shrines of Hazrat Diwan Chawali Mushaikh Burewala, Imam Ali al-Haq Sialkot, Shah Shams Subzwari Multan, Shah Kamal Lahore etc, the open lands attached to the shrines are rented out for Friday's and Sunday's temporary shops.

25 Waqf Organization collects almost $28 \%$ of its annual income under head of rents from the commercial units.

26 The term Shrine Complex is used for khanaqah as in modern days, the addition of various new components has transformed it into a new form. Naqvi \& Siddique Islamabad based consultants designed Data Darbar Complex Lahore

28 Prayer Hall is a large size arch with internal size 80'X120', constructed in RCC structure with inverted beams and hanging roof double slab. Other materials are Aluminum frame with safety glass in façade, stainless steel cones at minarets, ceramic tiles made in factory, alloy for grill, wrought iron and marble. 


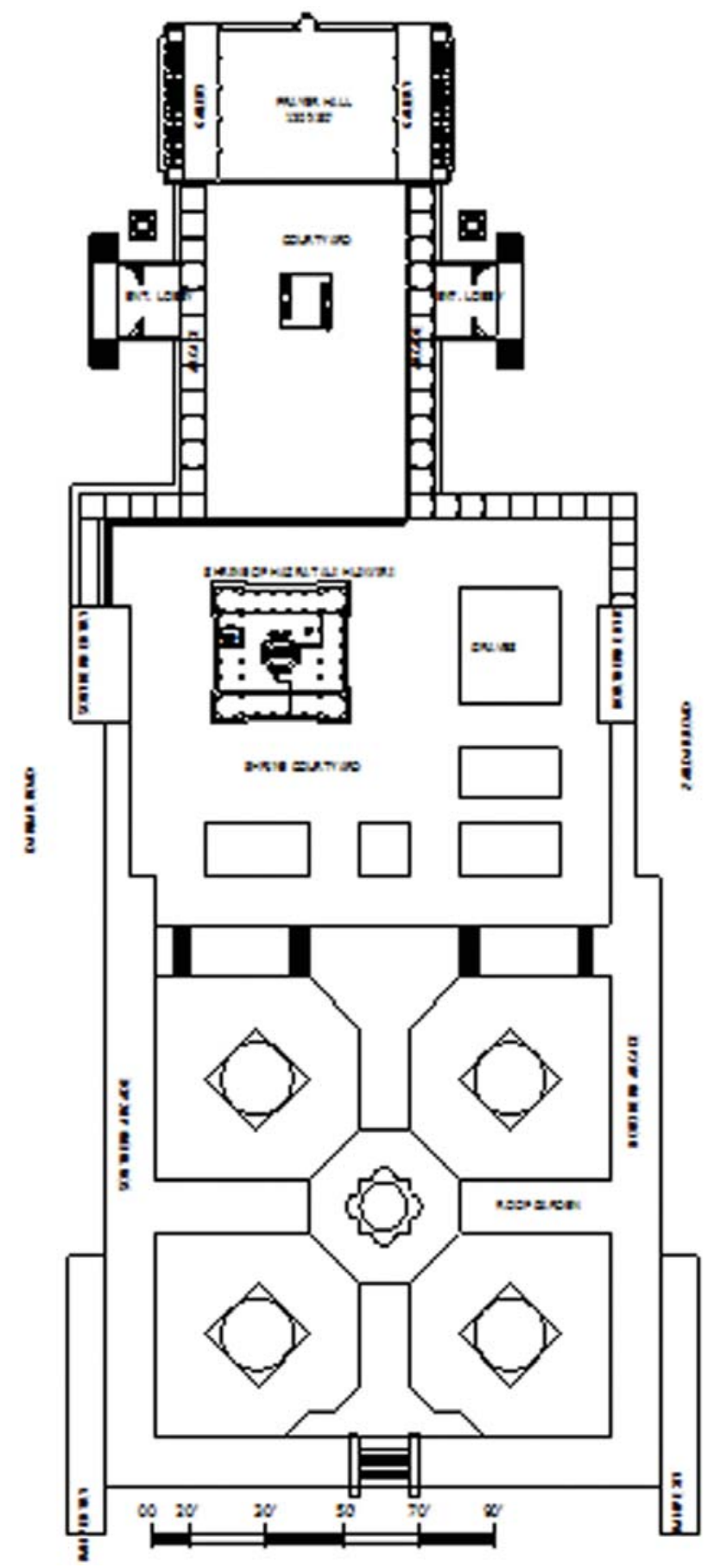

Figure-11: Master plan of Data Darbar complex Lahore (1981-1999). visited shrines of the Sufis, private land adjacent to the waqf properties is acquired under Land Acquisition Act 1894. For Data Darbar Complex, Baba Farid Complex etc, adjacent private land has been acquired. Waqf Department pays the price of land according to the prevailing market rates. For such forced land acquisitions, the owners sought help from the High Court and Supreme Court for their defense but the need of public being a top priority, their cases were dismissed. In recent years, waqf administration has planned to acquire land for expansion of shrine of Bibi Pak Damana Lahore and Shah Daula Daryai Gujrat. Such additional land changes the physical environment within the premises as well as outside the waqf property. The commercial value and landuse pattern of the Lower Mall Lahore changed, for case of expansion of Data Darbar and of Sahiwal Road for case of expansion of Baba Farid complex Pakpatten.

\section{CONDITIONS FOR FORMAL \& INFORMAL DEVELOPMENTS}

After taking the administrative control of shrines in 1960 by the waqf administration, the speed of formal and informal developments on the premises of khanaqahs increased. Before that, mutawallies and gaddi nashins were not interested in spending the money received from offerings of devotees on construction and expansion of the khanqahs. Rather they sold the attached waqf land to make the money out of it. The cash income received from the shrine was distributed among the mutawallies under mutually agreed system and no amount was spent on providing facilities to the visitors. Auqaf being an autonomous body meets its expenditures from the waqf income and most part of it is spent every year on up-gradation, reconstruction and restoration of shrines and its attached buildings.

The shrine of Baba Bulleh Shah, Shah Hussain, Abdul Salam Chishti Bara Bhai Masroor, Sakhi Turt Murad and many more were comprising of simple rooms and on demand of public and by the pressure of politically influential persons, these have been reconstructed by the waqf administration. The main approach road of Baba Farid khanqah was very narrow and with steep slope. It was essentially required to find out some solution. The northern door was reserved only for the family members of the gaddi nashin, hence a new entrance from the Sahiwal Road was introduced. For case of Shrine Hazrat Ali Hujwiri, it was desire of Zulifqar Ali Bhutto in year 1975 to extend its premises up to the extents of Lower Mall Road. The present design was approved by the design selection committee headed by then President of Pakistan as Chairman in 1981. Data Darbar Complex took twenty years to complete and governments subsequent 
provided funds for its construction. Its foundation stone was laid down by the President General Zia ul-Haq and complex was inaugurated by the then Prime Minister of Pakistan in 1999.

Construction of shrine complex of Waris Shah was initiated as a policy matter laid down by the Government in early years of 1970's when Chief Minister Punjab took initiative. It completed in ten years. For the case of Baba Bulleh Shah Complex Kasur, it was direction of a military official deputed for looking after the affairs of district Kasur, to reconstruct the shrine and mosque along with other attached facilities in 2002. The funds were provided by the provincial and federal governments. Zaireen Complexes at the shrine of Hazrat Sakhi Sarwar in Dera Ghazi Khan and Khawaja Ghulam Farid Kot Mithhan were constructed on the pressing demand of gaddi nashins and expenditures were borne by waqf administration. In year 1995-96, re-construction of the shrine of Hazrat Bibi Pak Damanan was initiated in pursuance to the direction of the then Prime Minister of Pakistan when she approved the design of new mosque Baba Farid and sanctioned Rs 120.00 million for its construction. For expansion of the shrine of Hazrat Bibi Pak Damanan, a parliamentarian succeeded in obtaining fund allocation for the required works during fiscal year 2011-12. In short, these formal and informal developments have been introduced on the premises of Sufi shrines by the rulers through public funds, by gaddi nashins or devotees through waqf administration.

\section{CONCLUSION}

The formal and informal developments on the premises of waqf properties have transformed the socio-religious and built environment of the shrines into a new idiom. Construction of new building structures not only changed the physical environment but also developed new interrelationships between various spaces occupied for performance of rituals and ceremonies. These new spatial configurations have set new patterns for flow of zaireen and spiritual ambiance of the shrine. Today, newly constructed shrines have different physical and spiritual ambiances as compared to those shrines which have not yet undergone such changes in context of their socio-religious and built environment. ${ }^{29}$

The construction of large size mosque has become a dominating component on the premises of shrine. Its religious differentiation divides the space into two, one for shrine ceremonies and other for the mosque- related rituals. The areas where new large size mosques were constructed, such shrines have become mosque complexes instead of shrine complexes. The parallel performance of the shrine-related ceremonies and mosque-related rituals has inter-mingled the spatial configuration of the shrine complex. This confusion has damaged the unique and identifiable ambiance of the shrine. There was a time when visitors were used to come only for the Sûfî but now, they visit shrine for saying their daily prayers in the mosque attached.

The performance of ceremonies and rituals at the shrines is no more in the hands of mutawallis and gaddi nashins. The shrines and their related activities including the collection of endowments, awarding the annual contracts of waqf agricultural lands, collection of rents from waqf properties, leasing out land in Punjab is administratively controlled by the Government of Punjab through its Auqaf \& Religious Affairs Department. The socio-religious and built environment of shrine is continuously changing with the passage of time, according to the requirements of the zaireen. Visitors think that to participate in the ceremonies and rituals performed at shrine are their main objective of visitation. The functional buildings are added on the premises of shrine complex to facilitate the za'ireen. ${ }^{30}$ These buildings if constructed properly are not a threat to the ambience and identity of the shrine. However, the new evolving trend of re-construction of a big Jâmi'a mosque dominating the shrine is a cause of architectural concern. ${ }^{31}$ This has encouraged the trend among public of performing their prayers in a mosque preferably attached to some Sufi shrine. ${ }^{32}$

29 Mostly the shrines in the south Punjab like Dai'ra Din Panah, Pir Ahmed Qatal, Pir Aadil, Hazrat Sakhi Sarwar, Hazrat Shah Rukn-e Aalam, Makhdome Jahanian Jahangusht, Jalal al-Din Surkhposh, Mahboob-e Subhani etc have experienced minimum changes in their socio-religious and built environment.

30 For example, seminar hall, library, air conditioning systems, police sub-station, lost and found centre, industrial school for women etc are added.

31 In the last decade of 20 century, Punjab Government has constructed large-scale mosques at shrines of Hazrat 'Ali Hujwiri Lahore, Baba Bulleh Shah Qasur, Shah Hussain Lahore and Baba Farid Pakpattan.

32 It has been observed that numbers of people coming to say their prayer are far less in Badshahi Mosque as compare to the mosque attached to the shrine of Hazrat 'Ali Hujwiri at Lahore. 


\section{REFERENCES}

Hasan, S.K. (2001) The Islaic Architectural Heritage of Pakistan; Karachi: Royal Book Company.

Khan, A.N. (1990) Islamic Architecture of Pakistan; Islamabad: National Hijra Council.

Khan, A.N. (1991) 'Evolution and Development of Islamic Funerary Memorial Architecture in Pakistan;, in Sultanate Period Architecture; Anjuman-e-Mimaran, Lahore.

Khan, A.N. (2003) Islamic Architecture in South Asia; Islamabad: National Hijra Council.

Mumtaz, K.K. (1985) Architecture in Pakistan; Singapore: Concept Media Ltd. 